accord with an earlier determination of W. Herschel's (roh. $16 \mathrm{~m} .7 \mathrm{~s}$. ), but involves a scrious correction of the value roh. 29m. I7s. given in most of the text-books. The error probably came from a servile copying of a slip of the pen made by some book-compiler, fifty years ago or more, in accidentally writing Herschel's value of the rotation of the inner ring, instead of that of the planet.

Much time has been spent in observations of the rings, and Trouvelot has reported a number of remarkable phenomena, most of which, however, he alone has seen as yet. The most recent micrometric measures have failed to confirm Struve's suspicion that the rings are contracting on the planet. Extensive series of observations have been made upon the satellites by H. Struve, Meyer, and others in Europe, and by Hall in this country. Hall's observations are especially valuable, and the series is now so nearly completed that we may soon hope to have most accurate tables. In the casc of Hyperion, there is found a singular instance of a retrograde motion of the line of apsides of the orbit, produced by the action of an outside body, the effect being due to the near commensurability of the periods of Hyperion and Titan. This most peculiar and paradoxical disturbance first showed itself as an observed fact in Hall's observations; and, soon after, Newcomb gave the mathematical explanation and development. IIe finds the mass of Titan to be about $1 / 12,500$ that of Saturn. It may be noted, too, that Hall's observations of the motions of Mimas and Enceladus indicate for the rings a mass less than $\mathbf{I} / \mathbf{I} 0$ that deduced by Bessel : instead of being $I /$ roo as large as the planet, they cannot be more than $\mathbf{I} / 1000$, and are probably less than I/I0,000.

The satellites of Uranus have also been assiduously observed at Washington, so that at present the Uranian system is probably as accurately determined as the Jovian, perhaps more so. The form of the planet has been shown to be decidedly elliptical (about 1/14) by observations of Schiaparelli and at Princeton: and the same observers have detected faint belts upon the disk, which have also been seen at Nice, and by the Henrys in Paris. Many of the observations appear to indicate a very paradoxical fact--that the belts, and consequently the planet's equator, are inclined to the orbits of the satellites at a considerable angle. The mathematical investigations of Tisserand appear to demonstrate that, in the case of a planet perceptibly flattened at the poles, satellites near enough to be frec from much solar disturbance must revolve nearly in the plane of the equator; while those more remote, and disturbed more by the sun than by the protuberant equator of the planet, must revolve nearly in the plane of the planet's orbit. Thus the two satellites of Mars, the four satellites of Jupiter, and the seven inner satellites of Saturn, all move nearly in the equatorial plane, while our moon and Japetus move in ecliptical orbits. It is very difficult to believe that the satellites of Uranus, which are certainly not ecliptical and are very near the planet, do not move equatorially. And yet it is unquestionable that most of the observations with sufficiently powerful telescopes (my own amung them) do seem to indicate pretty decidedly that the planct's equator is inclined as much as $15^{\circ}$ or $20^{\circ}$ to the orbit plane of the satellites.

As to Neptune, there is nothing new. One or two old observations of the planet have turned up in the revision of old star catalogues, and Ifall, of Washington, has made a careful and accurate determination of the orbit of its one satellite, and of the planet's mass; while Maxwell Hall, of Jamaica, has deduced a very doubtful value of the planet's rotation from certain photometric observations of its brightness.

There has been some hope that a planet beyond Neptune might be found. Guided by certain slight indications of systematic disturbances in the motion of Neptune, Todd made an extended search for it in $1877-78$, using the Washington telescope, and hoping to detect it by its disk, but without results. If such a planet exists, it is likely to appear as a star between the IIth and I 3 th magnitude, and may be picked up any time by the asteroid-hunters. But its slow motion, and the fact that our present charts give but few stars below the $1 x_{2}^{1}$ magnitude, will sender the recognition difficult

The indications I have spoken of, and certain others first noted in 1880 by Prof. G. Forbes, and depending upon the hehaviour of certain periodic comets, furnish pretty strong reasons fur believing in its existence, though as yet they fall far short of making it certain.

( $T o$ be continued.)

\section{A LECTURE EXPERIMENT ON THE EXPANSION OF SOLIDS BY HEAT}

I VENTURE to call attention to a simple and effective way of demonstrating the linear cxpansion of solids when heated, first suggested, I believe, by M. Kapoustine (Fournal de Physique, December I883, p. 576). It answers at least as well as the system of levers known as "Ferguson's pyrometer," which is usually employed for the purpose, while the cost of the apparatus is almost nothing, and any one can make it in ten minutes.

The principle is, to magnify the slight extension of a bar by causing the end of it to roll upon a needle, and thus turn the latter round and move a pointer attached to it through a sensible arc.

The figure given below will show the nature of the apparatus.

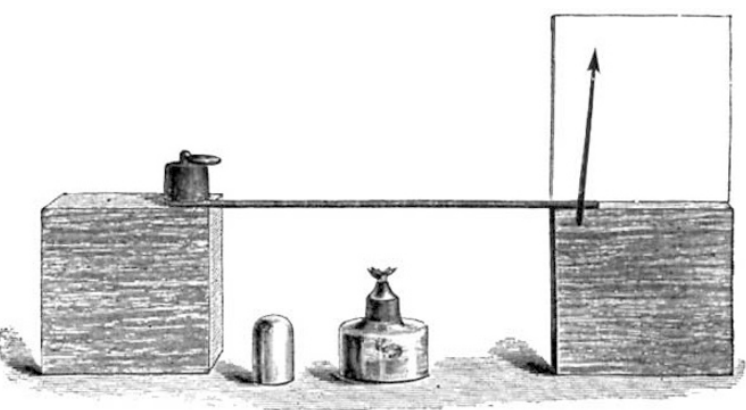

A small flat rod of the material to be examined, such as brass, iron, or glass, about $30 \mathrm{~cm}$. long, $1 \mathrm{~cm}$. broad, and 2 or $3 \mathrm{~mm}$. thick, is laid upon two wooden blocks, placed about $25 \mathrm{~cm}$. apart. A weight is put upon one end of the rod to keep it from moving; under the other end, at right angles to the length of the rod, is laid a fine sewing-needle, to the eye-end of which a light pointer of straw, about 16 or $20 \mathrm{~cm}$. long, is attached by sealing-wax. Behind the pointer (which is painted black) a screen of white cardboard is fixed on the wooden block by drawing-pins.

When the rod is heated by a lamp-flame, the free end of it, as it expands, moves forward upon the needle and rolls it round, its movement being shown by the motion of the pointer. Even the slight expansion of a slip of glass is thus easily rendered evident to a class.

I have constructed for my own use a double apparatus on the same principle, in which the surfaces between which the needle rolls are of brass, ground true and flat. Two bars of different materials lie side by side, each having its own bit of needle and aluminium pointer, ranging over the same scale. They are heated equally by a broad flame (spirits of wine in a wide trough) and the difference of expansibility as well as the fact of expansion by heat is thus shown.

It is advisable to counterpoise the pointer by putting a shot or two into the lower end of the straw which projects below the needle, and cementing them in by sealing-wax. Also, before the experiment is shown to an audience, it is well to make sure that the needle rolls fairly and freely between the bar and the block. Such precautions, however, are not in the slightest degree necessary for school-work; for there is always one thing which gives the typical boy greater pleasure than to see an experiment succecd, and that is-to sce it fail.

Eton Colloge

II. G. MADAN

COMPARATIVE STUDIES UPON TIIE GLACIATION OF NORTH AMERICA, GREAT BRITAIN, AND IRELAND

BSERVATIONS extending over several years upon glacial phenomena on bolh sides of the Atlantic had convinced the author of the essential identity of these phenomena; and the object of this paper was to show that the glacial deposits of Great Britain and Ireland, like those of America, may be interpreted most satisfactorily by considering them with reference to a series of great terminal moraines, which both define confluent

I Abstract of a Paper read at the Birmingham meeting of the British I Abstract of a Paper read at the Birmingham meeting of the Briation, September 1886 , by Prof. H. Carvill Lewis, M.A., k.G.S.
Association 
lobes of ice and also often mark the line separating the glaciated from the non-glaciated areas.

The pajer began with a sketch of recent investigations npon the glaciation of North America, with special reference to the significance of the terminal moraines discovered within the last few years. The principal characters of these moraines were given, and a map was exhibited showing the extent of the glaciated areas of North America, the course of the interlobate and terminal moraines, and the direction of striation and glacial movement. It was shown that, apart from the great ice sheet of North-Eastern America, an immense lobe of ice descended from Alaska to Vancouver's Island on the western side of the Rocky Mountains, and that from various separate centres in the Cascade, Sierra Nevada, and Rocky Mountains there radiated smaller local glaciers.

The mountains encircling the depression of I Hudson Bay seemed to be the principal source of the glaciers which became confuent to form the great ice-sheet. In its advance, this ice sheet probably met and amalgamated with a number of already existing local glacial systems, and it was suggested that there was no necessity for assuming either an extraordinary thickness of ice at the Pole, or great and unequal elevations and depressions of land.

Detailed studies marle by the author in Ireland in 1885 had shown remarkably similar glacial phenomena.

The large ice-sheet which covered the greater part of Ireland was composed of confluent glaciers, while distinct and local glacial systems occurred in the non-glaciated area. The prin cipal ice-sheet resembled that of America in having for its centre a great inland depression surrounded by a rim of mountains.

These appear to have given rise to the first glaciers, which, after uniting, poured outwards in all directions. Great lobes of this ice-sheet flowed westward out of the Shannon and out of Galway, Clew, Sligo, and Donegal Bays, northward out of Loughs Swilly and Foyle, and south-eastward out of Dundalk and Dublin Bays; while to the south the ice-sheet abutted against the Mullaghareirk, Galty, and Wicklow Mountains, or died out in the plains.

Whether it stopped among the mountains or in the lowlands, its edge was approximately outlined by unusual accumulations of drift and boulders, representing the terminal moraines. As in America, this outer moraine was least distinct in the lowlands, and was often bordered by an outer "fringe" of drift several miles in width.

South of an east and west line extending from Tralee to Dungarvan is a non-glaciated zone free from drift. Several local systems of glaciers occur in the South of Ireland, of which by far the most important is that radiating from the Killarney Mountains, covering an area of 2000 square miles, and entitled to be called a local ice-sheet. Great glaciers from this Killarney ice-sheet flowed out of the fjord-like parallel bays which indent the south-western coast of Ireland. At the same time the Dingle Mountains, the Knockmealdown and Comeragh Mountains, and those of Wexford and Wicklow furnished small separate glaciers, each sharply defined by its own moraine.

No evidence of any g eat marine : ubmergence was discovered, although the author had explored the greater part of Ireland, and the eskers were held to be phenomena due to the melting of the ice and the circulation of sub-glacial waters. The Irish icesheet seemed to have been joined at its north-castern corner by ice coming from Scotland across the North Channel. All the evidence collected indicates that a mass of Scotch ice, reinforced by that of Ireland and England, filled the Irish Sea, over-riding the Isle of Man and Anglesey, and extènding at least as far south as Bray Head, south of Dublin. A map of the glaciation of Ireland was exhibited in which the ob ervations of the Irish geologists and of the author were combined, and in which was shown the central sheet, the five local glacial systems, all the known strix, and the probable lines of movement as indicated by moraines, strix, and the transport of erratics.

The glaciation of Wales was then considered. Wales was shown to have supported three distinct and disconnected local systems of glaciers, while at the same time its extreme northern border was touched by the great ice-lobe filling the Irish Sea. The most extensive local glaciers were those radiating from the Snowdon and Arenig region, while another set of glaciers radiated from the Plinlimmon district and the mountains of Cardiganshire, and a third system originated among the Brecknockshire Beacons. The glaciers from each of these centres transported purely local boulders and formed well-defined terminal moraines. The northern ice-lobe, bearing granite boulders from Scotland and shells and flints from the bed of the Irish Sea, invaded the northern coast, but did not mingle with the Welsh glaciers. It smothered Anglesey and part of Car narvonshire on the one side and part of Flintshire on the other, and heaped up a terminal moraine on the outer flanks of the Nortl Welsh mountains. This great moraine, filled with fartravelled northern erratics, is heaped up in hummocks and irregular ridges, and is in many places as characteristically developed as anywhere in America. It has none of the characters of a sea-beach, although often containing broken shells brought from the Trish Sea. It may be followed from the extreme end of the Lleyn Peninsula (where it is full of Scotch granite erratics), in a north-easterly direction through Carnarvonshire past Moel Tryfan and along the foot of the mountains east of Menai Strait to Bangor, where it goes out to sea, re-appearing further east at Conway and Colwyn. It turns south-eastward in Denbighshire, going past St. Asaph and Halkin Mountain. In Flintshire it turns southward, and is magnificently developed on the en tern side of the mountains, at an elevation of over 1000 feet, between Minera and Llangollen, south-west of which place it enters England. There is evidence that, where the ice-sheet abutted against Wales, it was about 1350 feet in thickness. This is analogous to the thickness of the ice-sheet in 'ennsylvania, where the author had previously shown that it was about roos feet thick at its extreme edge, and 2000 feet thick at points some 8 miles back from its elge. The transport of erratics coinciles with the direction of stria in Wales as elsewhere, and is at right angles to the terminal moraine.

The complicated phenomena of the glaciation of England, the subject of a voluminous literature and discordant views, had been of high interest to the author, and had led him to redouble his efforts for its solution. He had found that it was possible to accurately map the glaciated areas, to separate the deposits made by land ice from those dne to icebergs or to torrential rivers, and to trace out a serjes of terminal moraines both at the edge of the ice-sheet and at the elge of its confuent lobes. Perhaps the finest exhibition of a terminal moraine in England is in the vicinity of Ellesmere, in Shropshire. A great mass of drift several miles in width, and full of erratics from Scotlanil and from Wales, is here heaped up into conical hills which inclose "kettle holes" and lakes, and have all the characters of the "kettle-moraine" of Wisconsin. Like the latter, the Ellesmere moraine here divides two great lobes of ice, one coming from Scotland, the other from Wales. This moraine may be traced continuously from Ellesmere eastward through Matleley, Macclesfirld, to and along the western flank of the Pennine Chain, marking throughout the southern edge of the ice-sheet of northern England. From Macclesfield the same moraine was traced northward past Stockport and Staleybridge to Burnley, and thence to Skipton in Yorkshire. North-east of Burnley it is banked against the Boulsworth Hills up to a height of I 300 feet in the form of mounds and hummocks. South and east of this long moraine no signs of glaciation were discovered, while north and west of it there is every evidence of a continuous ice-sheet covering land and sea alike. The striæ and the transport of boulders agree in proving a southerly and south-easterly direction of ice-movement in Lancashire and Cheshire.

From Skipton northward the phenomena are more complicated. A tongue of ice surmounted the watershed near Skipton, and protruded down the valley of the Aire as far as Bingley, where its terminal moraine is thrown across the valley like a great dam, reminding one of similar moraine dams in several Pennsylvania valleys. A continuous moraine was traced around this Aire glacier. Another great glacier, much larger than this, descended Wensleydale and reached the plain of Vork. The most complex glacial movements in England occurred in the mountain region about the Nine Standards, where local glaciers met and were overpowered by the greater ice-sheet coming down from Cumberland. The ice-sheet itself was here divided, one portion going southward, the other in company with local glaciers and laden with the well-known boulders of "Shap granite" being forced eastward across Stainmoor Forest into Durham and Yorkshire, finally reaching the North Sea at the mouth of the Tees. The terminal moraine runs eastward through Kirkby Ravenwworth, toward Whitby, keeping north of the Cleveland Hills, and all Eastern England south of Holderness appears to be non-glaciated. On the other hand, all England north of Stainmoor Forest and the River Tees, except the very highest points, was smothered in a sea of solid ice. 
There is abundant evidence to prove that the ice-lobe filling the Irish Sea was thicker towards its axis than at its edges, and at the north than at its southern terminus, and that it was reinforced by smaller tributary ice-streams from both England and Ireland. It may be compared with the glacier of the Hudson River Valley in New York, each having a maximum thickness of something more than 3000 feet. The erosive power of the ice-sheet was found to be extremely slight at its edge, but more powerful farther north, where its action was continued for a longer period. Towards its edge its function was to fill up inequalities rather than to level them down. It was held that most glacial lakes are due to an irregular dumping of drift, rather than to any scooping action, observations in England and in Switzerland coinciding with those in America to confirm this conclusion. Numerous facts on both sides of the Atlantic indicate that the upper portion of the ice-sheet may move in a different direction from its lower portion. It was also shown that a glacier in its advance had the power of raising stones from the bottom to the top of the ice, a fact due to retardation by friction of its lower layers. The author had observed the gradual upward passage of sand and stones in the Grindelwald glacier, and applied the same explanation to the broken shells and flints raised from the bed of the Irish Sea to the top of Moel Tryfan, to Macclesfield, and to the Dublin mountains.

The occurrence of stratified deposits comected with undoubted moraines, was shown to be a common phenomenon, and instances of stratified moraines in Switzerland, Italy, America, and Wales, were given. The stratification is due to waters derived from the melting ice, and is not proof of submergence.

It was held that, notwithstanding a general opinion to the contrary, there is no evidence in Great Britain of any marine submergence greater than about 450 feet. It was to be expected that an ice-sheet advancing across a sea-bottom should deposit shell-fragments in its terminal moraine. The broad principle was enunciated that wherever in Great Britain marine shells occur in glacial deposits at high levels, it can be proved both by striæ and the transport of erratics that the ice advanced on to the land from out of the sea. The shells on Three Rock Mountain near Dublin, and in North Wales and Macclesfield, all from the Irish Sea; the shells in Cumberland transported from Solway Firth; those on the coast of Northumberland brought out of the North Sea; those at Airdrie in Scotland, carried eastward from the bottom of the Clyde; and those in Caithness from Moray Firth, were among examples adduced in proof of this principle. The improbability of a great submergence not leaving corresponding deposits in other parts of England was dwelt upon.

It was also held that there was insufficient evidence of more than one advance in the ice-sheet, although halts occurred in its retreat. The idea of successive elevations and submergences with advances and retreats of the ice was disputed, and the author held that much of the supposed inter-glacial drift w'as due to sub-glacial waters from the melting ice.

The last portion of the paper discussed the distribution of boulders, gravels, and clays south of the glacial area. Much the greater part of England wa : believed to have been uncovered by land ice. The drift deposits in this area were shown to be the result in part of great fresh-water streams issuing from the melting ice-sheet and in part of marine currents bearing icebergs during a submergence of some $45^{\circ}$ feet. The supposed glacial drift about Birmingham and the concentration of boulders at Wolverhampton were regarded as due to the former agent, while the deposits at Cromer and the distribution of Lincolnshire chalk across Southern England were due to the latter. The supposed esker at Hunstanton was held to be simply a sea-beach, and the London drift deposits to be of aqueous origin. Thus the rival theories of floating icebergs and of land glaciers were both true, the one for Middle and Southern England, the other for ScotJand, Wales, and the North of England; and the line of demarkation was fixed by great terminal moraines. The paper closed with an acknowledgment of indebtedness to the many geologists in England and Ireland who had uniformly rendered generous assistance during the above investigation.

THE CLIMATE OF NORTHERN EUROPE AND THE GULF STREAM

I $\mathbf{N}$ view of the reference made by Sir William Dawson, in his inaugural address at the meeting of the British Association, to the effect of the Gulf Stream on the climate of Northern
Europe, particularly that of Norway, and the consequences of a diversion of the stream from its present course, the following contribution to the subject by the well-known Norwegian savant, Dr. Karl Hesselberg, which appeared in a recent number of the scientific journal Naturen, may be of interest and tend to its further elucidation.

According to the situation of Norway on the globe, the northern part of the country should have a clistinct Polar climate, with eternal ice and snow, a home only for the Eskimo and Polar bears. Several circumstances contribute, however, to make it otherwise. The country forms a western promontory of the great Asiatic-European continent, and receives its full share of the advantages of such a situation. Mild south-west winds blow throughout the year, while warm sea-currents wash its extensive shores summer as well as winter. The winter cold is so reduced that only a small portion of the heat of the summer sun is consumed in melting the snow. The length of the summer days, too, which north of the Polar Circle last twenty-four hours, contribute to raise the mean temperature, and accelerate the growth of the flora. Certain other circumstances, as, for instance, the formation of the country and the physico-geographical conditions of the North Atlantic Ocean, contribute equally to make the Norwegian climate one of the most favourable in the world. A brief résumé of the circumstances will be of interest.

A chart of the distribution of the atmospheric depression in the North Atlantic Ocean-the Norwegian Sea-shows that all the year round a strong barometric minimum prevails in the middle of the sea between Norway, Iceland, Jan Mayen, and Spitzbergen, the consequence of which is that south-west winds always blow in the eastern part of this area, viz. along the coast of Norway. Warm water is thereby forced up towards Norway and Spitzbergen, even into the East Arctic Ocean. The bottom formation of the sea, too, contributes to preserve the high temperature. If a chart be exrmined of the depths of the North Atlantic Ocean, such a one, for instance, as is the result of Prof. Mohn's labours after the measurements of the Norwegian North Atlantic Expedition, it will be found that the sea-bottom between Norway, the Faroe Islands, Iceland, and Jan Mayen, forms a basin with a depth of a little over 2000 English fathoms. It will also be seen that the Norwegian coast does not fall abruptly into this abyss, but that the bottom alonis the whole coast slopes gradually down from the shore seawards to a certain point where it terminates perpendicularly. In other words, Norway is surrounded with a contintous " bank," which in a great measure contributes to preserve the high temperature along the coast. In the great basin, however, the water is icy cold at the bottom, but against this the bank forms a natural barrier, whilst above the bank the warm water is without any bottom layer of cold. It is the warm water which fills the fjords and there preserves a temperature so high that it is sometimes higher than the mean temperature of the air, and under which the fjords do not freeze, a circumstance of great importance. If the temperature of the sea-water in the winter contributes to raise the temperature of the air, it will in the summer have the opposite effect, and cause the climate to be very much tempered along the coast. It is only in the fjords and adjacent valleys that the temperature in the summer rises to a height unusual for the latitude.

In order to show the relatively favourable climate which Norway enjoys, Dr. Hesselberg supplies two diagrams. The first of these shows the mean temperature of the air over Europe and the North Atlantic Ocean in January, when it is lowest. Isotherms are shown for every fifth degree. If now, for instance, the isotherm $0^{\circ}$ - the temperature of the air - be followed, it will at once be seen how far it shoots up northwards between Iceland and Norway, in fact, right above lat. $70^{\circ} \mathrm{N}$. In tead of running east and west, it goes nearly straight north and south, particularly along the west coast of Norway, which it follows throughout its entire length, from the latitude of Tromsö to that of Christiansand. Hence it deviates towards Denmark, then runs into the Baltic, returns to Hamburg, and thence runs in a south-easterly direction across Europe, nearly down to the Adriatic Sea. Here it first trends eastwards, across Turkey and the Black Sea. Off the Norwegian coast, therefore, in lat. $70^{\circ} \mathrm{N}$., the same mean tempera. ture prevails in January as in Southern Europe in lat. $45^{\circ}$, and even there the mean temperature is probably $3^{\circ}$ higher than might be expected according to the latitude. The other isotherms have a similar course, as well as the temperature at the surface of the sea. A great wave of warm water rolls up 